\title{
The role of thiocyanate in the etiology of goiter in an industrial metropolitan area
}

\author{
V F H Brauer, H Below ${ }^{1}$, A Kramer ${ }^{1}$, D Führer and R Paschke \\ III. Department of Medicine, University of Leipzig, Ph.-Rosenthal-Str. 2704103 Leipzig, Germany and ${ }^{1}$ Institute for Hygiene and Environmental \\ Medicine, University of Greifswald, Greifswald, Germany
}

(Correspondence should be addressed to R Paschke; Email: Ralf.paschke@medizin.uni-leipzig.de)

\begin{abstract}
Objective: Thiocyanate $\left(\mathrm{SCN}^{-}\right)$has concentration dependent antithyroid properties and a role in the etiology of goiter has been suggested in several studies. In 1991 an epidemiological survey conducted in the region of Halle/Leipzig (Saxony), an area with significant air pollution, suggested an inverse relationship between urinary iodine $\left(\mathrm{I}^{-}\right) / \mathrm{SCN}^{-}$excretion and goiter prevalence. 10 years later, we reinvestigated the same industrial area to clarify if the situation has changed after the elimination of most industrial waste products and moreover, if $\mathrm{SCN}^{-}$excretion levels alone or in combination with air pollution or smoking as a $\mathrm{SCN}^{-}$source are critical for thyroid function.

Design and methods: We investigated a cohort of 708 probands for $\mathrm{I}^{-}, \mathrm{SCN}^{-}$and creatinine excretion in spot urine samples and determined the prevalence of goiter and thyroid nodules by high resolution ultrasonography.

Results: Probands with goiter $(n=79,11 \%)$ had significantly higher urinary $\mathrm{SCN}^{-}$excretions than probands without $\left(3.9 \pm 2.8\right.$ vs $3.1 \pm 3.4 \mathrm{mg} \mathrm{SCN}^{-} / \mathrm{g}$ creatinine) and significantly lower urinary

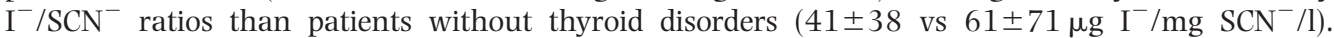
Mean urinary $\mathrm{I}^{-}$excretions were not different between probands with or without goiter. Smokers showed significantly elevated urinary $\mathrm{SCN}^{-}$/creatinine ratios in comparison to non-smokers $(4.3 \pm 4.3$ vs $2.4 \pm 2.1 \mathrm{mg} \mathrm{SCN} / \mathrm{g}$ creatinine). ANOVA revealed a prediction of thyroid volume through age $(P<0.001)$, gender $(P<0.001)$, body weight $(P<0.05)$ and smoking $(P<0.05)$. Conclusions: In our investigation, age, gender and smoking (raising $\mathrm{SCN}^{-}$levels by $\mathrm{CN}^{-}$inhalation) were predictive for thyroid volume and the urinary $\mathrm{I}^{-} / \mathrm{SCN}^{-}$ratios were able to detect probands with an increased risk of developing goiter in contrast to urinary $\mathrm{I}^{-}$excretion levels alone. These data suggest, that in an era and area of decreased cyanide pollution, $\mathrm{SCN}^{-}$may remain a cofactor in the multifactorial aetiology of goiter.
\end{abstract}

European Journal of Endocrinology $154229-235$

\section{Introduction}

Besides genetic determinants different environmental and individual factors are involved in the etiology of goiter, which can differ between geographic regions $(1-5)$. Iodine $\left(\mathrm{I}^{-}\right)$deficiency is the most important epidemiologic factor for endemic goiter. However naturally occurring goitrogenes may also contribute $(3,5$, 6). Thiocyanate $\left(\mathrm{SCN}^{-}\right)$occurs ubiquitously and has numerous biological and medically relevant effects. $\mathrm{SCN}^{-}$promotes cell growth, has protective properties in case of toxic and mutagenic cell exposure and stimulates the immune response and the phagocytosis (7). In addition $\mathrm{SCN}^{-}$affects thyroid function depending on the $\mathrm{SCN}^{-}$concentration. At low concentrations, stimulation of thyroid function was found (8) whereas at pathologically elevated concentrations $\mathrm{SCN}^{-}$acts as a competitive inhibitor of the
$\mathrm{I}^{-}$transport into the thyrocyte (9). Raw cabbage contains high doses of $\mathrm{SCN}^{-}$as well as other goitrogenes e.g. oxazolidone which have been supposed to harbour an even higher goitrogenous potential than $\mathrm{SCN}^{-}$ itself. Therefore, unbalanced nutrition with cabbage has been associated with increased thyroid volume and goiter (1). This may be relevant especially in regions with low $\mathrm{I}^{-} / \mathrm{SCN}^{-}$ratios caused by $\mathrm{I}^{-}$ deficiency and additional excessive consumption of cabbage (north eastern Sicily) and may thus contribute to the development of endemic goiter. In fact, goiter were present in up to $50 \%$ of school children in north eastern Sicily (1). Beside $\mathrm{SCN}^{-}$absorption through nutrients, $\mathrm{SCN}^{-}$is generated in the organism as a product of the cyanide-thiosulfate-mercaptopyrovate-sulfurtransferase-(Rhodanese)-system. It detoxicates cyanide $\left(\mathrm{CN}^{-}\right)$with thiosulphate to $\mathrm{SCN}^{-}$. If $\mathrm{CN}^{-}$is released in considerable quantities directly by 
industrial combustion or indirectly through industrial degradation processes this may result in pathological $\mathrm{SCN}^{-}$concentrations influencing the thyroid function $(7,10,11)$. In industrial areas increased $\mathrm{SCN}^{-}$ plasma and urinary $\mathrm{SCN}^{-}$excretion levels are indicative of exposure to industrial waste products. Another independent risk factor raising $\mathrm{SCN}^{-}$levels by $\mathrm{CN}^{-}$ inhalation is smoking (7). The generation of $\mathrm{SCN}^{-}$ through $\mathrm{CN}^{-}$differs according to the $\mathrm{SCN}^{-}$intake. An oral application of $32 \mathrm{mg} \mathrm{NaSCN} / \mathrm{kg}$ over 21 days to guinea pigs (100-fold above the normal alimentary intake) did not result in a histologic change of thyrocytes $(10,11)$. However, the oral application of bitter almonds in a concentration of $9.4 \mathrm{mg}$ $\mathrm{CN} / \mathrm{kg}$ was followed by a significant increase of thyroid volume and inhibition of $\mathrm{T}_{4}$ synthesis (11). Moreover pulmonary infections, occurring more often in industrial than in non-industrial areas, can contribute to elevated $\mathrm{SCN}^{-}$levels since inflammatory processes themselves may increase $\mathrm{SCN}^{-}$-levels $(7,10)$.

An epidemiologic survey, conducted in the region of Halle/Leipzig (Saxony) in 1991 revealed a relationship between urinary $\mathrm{I}^{-}$and $\mathrm{SCN}^{-}$excretions and goiter prevalence. Elevated urinary $\mathrm{SCN}^{-}$excretion levels were observed in healthy probands and patients with goiter in comparison to probands from Greifswald/Neubrandenburg (Pomerania) (10). In addition, the $\mathrm{I}^{-} / \mathrm{SCN}^{-}$ratios were lowest in the region of Halle/Leipzig with values of $<4 \mu \mathrm{g} / \mathrm{mg}$ (10). Since a drastic reduction of $\mathrm{CN}^{-}$pollution through industrial waste products has been achieved in the region of Halle/Leipzig over the last 10 years according to the World Health Organization recommendations for air quality $(12,13)$, whereas mild $\mathrm{I}^{-}$deficiency is still present (14) we decided to re-evaluate the relevance of $\mathrm{SCN}^{-}$levels with respect to goiter prevalence. For this reason we conducted a prospective study to investigate: 1) if the prevalence of goiter is correlated with urinary $\mathrm{SCN}^{-}$excretion, 2) if patients with goiter have a decreased urinary $\mathrm{I}^{-} / \mathrm{SCN}^{-}$ratio and 3 ) if the $\mathrm{I}^{-} / \mathrm{SCN}^{-}$ ratio is a better risk predictor for prevalence of goiter than urinary $\mathrm{I}^{-}$or $\mathrm{SCN}^{-}$excretion alone?

\section{Patients and methods}

We conducted a prospective trial in 2002. All probands lived in the area of Halle/ Leipzig (Saxony), a former industrial region. The probands were contacted by posters, university press and the university intranet website. The study was approved by the local Ethics Committee. All probands gave written informed consent. Probands were asked to give a spot urine sample and to fill in a questionnaire, asking for frequencies of intake of food with high $\mathrm{I}^{-}$content, such as milk and milk products, fish, cereals, meat products, iodized table salt as well as intake of $\mathrm{I}^{-}$containing tablets, pregnancy or lactation period and a history of smoking.
We are aware that investigating 'healthy' volunteers can cause a selection bias. However, randomly selecting volunteers by outward manifestation of a 'disease' is a valid model for a clinical prospective trial and can be used in cohort and cross-sectional studies aiming at decreasing selection bias.

The $\mathrm{I}^{-}$-, creatinine-and $\mathrm{SCN}^{-}$concentrations in spot urine samples were determined in 708 probands. Iodine concentration was measured according to the protocol described by Sandell and Kolthoff, which is based on the catalytic role of $\mathrm{I}^{-}$in the reduction of ceric ammonium sulphate in the presence of arsenious acid $(15,16)$. Creatinine was measured as described by Jaffe (17) and $\mathrm{SCN}^{-}$concentration was measured according to the method described by Below and Weuffen (straight line calibration method in accordance with German Standards Organization, DIN 32 645) (18). After denaturation with trichloracetic acid, $\mathrm{SCN}^{-}$will converted by Chloramine-T into Chlorcyan, which is determined in a photospectrometic reaction $(585 \mathrm{~nm}$ ) (Spekol 211, Carl Zeiss Jena, Jena, Germany) in the presence of a barbitural acid-pyridine reagent. Analytical characteristics for the determination of $\mathrm{SCN}^{-}$in urine were as follows:

- detection limit: $0.043 \mathrm{mg} \mathrm{SCN}^{-} / \mathrm{l}$

- determination limit: $0.105 \mathrm{mg} \mathrm{SCN}^{-} / \mathrm{l}$

- recording limit: $0.153 \mathrm{mg} \mathrm{SCN}^{-} / \mathrm{l}$

- between day CV: $\pm 3.0 \%$, within day $\mathrm{CV}: \pm 4.2 \%$

- linear region of the calibration straight line: determination limit to $50 \mathrm{mg} \mathrm{SCN}^{-} / 1$

- functional sensitivity: $0.02 \mathrm{l} / \mu \mathrm{mol} \mathrm{SCN}$

- retrieval rate in urine: $<1 \mathrm{mg} / \mathrm{l}$ 92.1-106.9\% > $1 \mathrm{mg} / \mathrm{l}$ 96.0-104.0\%

- interfering anions: from the anions in biological materials only $\mathrm{CN}^{-}$interferes.

However, in urine, $\mathrm{CN}^{-}$has a 100-1000-fold lower concentration than $\mathrm{SCN}^{-}$. $\mathrm{SCN}^{-}$excretion and $\mathrm{I}^{-}$ excretion were correlated with creatinine excretion in every spot urine sample to minimize bias through kidney function and variable 24-hour urinary volume (19). To reduce statistical bias, probands with $\mathrm{I}^{-}$contamination defined as urinary $\mathrm{I}^{-}$excretion $>300 \mu \mathrm{g}$ $\mathrm{I}^{-} / \mathrm{g}$ creatinine $(20,21)$ were excluded from further analysis.

Ultrasound was performed using a high resolution realtime instrument $\left(7.5 \mathrm{MHz}\right.$ ) (Siemens Sonoline ${ }^{\circledR}$ Adara Siemens Medical Systems, Erlangen, Germany). Thyroid volumes were calculated according to the spherical ellipsoid formula: volume $=\pi / 6 \times$ anteroposterior diameter $(\mathrm{cm}) \times$ width $(\mathrm{cm}) \times$ length $(\mathrm{cm}) \quad(22,23)$. Thyroid volumes greater than $18 \mathrm{ml}$ were considered to be enlarged in adult women and thyroid volumes greater than $25 \mathrm{ml}$ were considered to be enlarged in adult men, which corresponds to the mean +3 s.D. in $\mathrm{I}^{-}$sufficient populations (24) and guaranteed, that gender specific values for goiter are above the 97 th percentile of thyroid volumes found in $\mathrm{I}^{-}$replete control population (21). 
Statistical analyses were performed using SPSS software, version 10.0 (SPSS GmbH Software, Munich, Germany). We used means instead medians for statistical analysis of $\mathrm{I}^{-}$and $\mathrm{SCN}^{-}$excretion levels because there was a symmetrical distribution of the data. Moreover, the statistical bias in large cohorts ( $>500$ probands) is lower when using mean values than median values as mean values better describe metric variables than the median values $(25,26)$. Multivariable comparisons between the groups were performed with ANOVA (endpoints thyroid volume and urinary $\mathrm{I}^{-}$excretion). Adjustments were made for age, smoking and gender. A value of $P<0.05$ was considered statistically significant.

\section{Results}

\section{Correlations between urinary $\mathrm{SCN}^{-}$excretions of subpopulations and thyroid volume}

Urinary $\mathrm{SCN}^{-}$excretion (mg SCN ${ }^{-} / \mathrm{g}$ creatinine) correlated positively with thyroid volume (Pearson correlation coefficient 0.097 , significant at the 0.01 level, [2-tailed]) and was similar in men and women (male: $2.9 \pm 2.6$ vs female: $3.3 \pm 3.5 \mathrm{mg} \mathrm{SCN}-/ \mathrm{g}$ creatinine). Probands with (nodular) goiter $(n=79)$ had significantly higher urinary thiocyanate/creatinine excretion ratios in comparison to probands with normal thyroid volume ( $t$-test, $P<0.05$, [2-tailed]) (Table 2). Gender specific statistical analysis revealed a significantly elevated $\mathrm{SCN}^{-}$excretion for females with goiter in comparison to females without ( $t$-test, $P<0.05$, [2-tailed], Table 2). Moreover, the $\mathrm{SCN}^{-}$excretion is significantly elevated in pregnancy and lactation period (Table 2).

\section{Correlations between urinary $\mathrm{I}^{-}$excretions of subpopulations and thyroid volume}

Hence urinary $\mathrm{I}^{-}$excretion levels alone did not correlate with thyroid volume of the study population (sex and age corrected analysis). Mean urinary $\mathrm{I}^{-}$excretion levels were lower in probands with (nodular) goiter than in probands with normal thyroid volume (Table 2) without reaching statistical significance. The mean urinary $\mathrm{I}^{-}$excretion $\left(108 \pm 81 \mu \mathrm{g} \mathrm{I}^{-} / \mathrm{g}\right.$ creatinine, i.e. $102 \mu \mathrm{g} / \mathrm{l}$, Table 2) in our cohort was within the lower range of adequate $\mathrm{I}^{-}$intake (100$200 \mu \mathrm{g} / \mathrm{g})(20,21)$. Of 79 probands with goiter only 15 showed moderate $\left(25-49 \mu \mathrm{g} \mathrm{I} \mathrm{I}^{-} / \mathrm{g}\right.$ creatinine) to severe $\left(<25 \mu \mathrm{g} \mathrm{I}^{-} / \mathrm{g}\right.$ creatinine $) \mathrm{I}^{-}$deficiency $(20,21)$.

\section{Urinary $\mathrm{I}^{-} / \mathrm{SCN} \mathrm{N}^{-}$ratios and goiter}

The $\mathrm{I}^{-} / \mathrm{SCN}^{-}$ratio of the total study population was negatively correlated with thyroid size (Pearson correlation coefficient -0.079 significant at 0.05 level [2-tailed], Table 2). Probands with (nodular) goiter $(n=79)$ had significantly lower urinary $\mathrm{I}^{-} / \mathrm{SCN}^{-}$ ratios in comparison to probands with normal thyroid volume (Table 2, $t$-test, $P<0.05$, [2-tailed]). Gender specific analysis revealed significant differences in urinary $\mathrm{I}^{-} / \mathrm{SCN}^{-}$ratios between probands with and without goiter. Females with goiter (Table 2) showed lower urinary $\mathrm{I}^{-} / \mathrm{SCN}^{-}$ratios than females without $\left(n=506 ; 63 \pm 75 \mu \mathrm{g} \mathrm{I}^{-} / \mathrm{mg} \mathrm{SCN}^{-} / \mathrm{l}\right)$. Equally, males with goiter (Table 2) had lower urinary $\mathrm{I}^{-} / \mathrm{SCN}^{-}$ ratios than males without $(n=123 ; 49 \pm 50 \mu \mathrm{g}$ $\left.\mathrm{I}^{-} / \mathrm{mg} \mathrm{SCN}^{-} / \mathrm{l}\right)(t$-test, $P<0.05$, [2-tailed]).

\section{Smoking and thyroid volume}

Four hundred ninety one $(69.4 \%)$ probands answered the question for a history of smoking. 217 probands $(30.6 \%)$ failed to give an answer. Three hundred sixty seven from 491 probands $(74.7 \%)$ were non-smoker and 124/491 (25.3\%) were smoker. Mean thyroid volume was higher in smokers than in non-smoking probands without reaching statistical significance (Table 3, t-test, $P=0.085, \quad$ [2-tailed]). Thyroid volume correlated positively with the reported pack years of the smokers (Pearson correlation coefficient 0.124 significant at the 0.01 level [2-tailed]). Renal $\mathrm{SCN}^{-}$excretion in $\mathrm{mg} \mathrm{SCN}^{-} / \mathrm{g}$ creatinine did not correlate with thyroid volume in smokers $(P=0.6)$ and showed a correlation in non-smokers $(P=0.068)$. Urinary $\mathrm{I}^{-} / \mathrm{SCN}^{-}$ratios correlated negatively with thyroid volume in 124 smokers (Pearson correlation coefficient -0.183 significant at the 0.05 level [2-tailed]). Additionally, smokers showed significantly elevated urinary $\mathrm{SCN}^{-} /$creatinine ratios and lower urinary $\mathrm{I}^{-} / \mathrm{SCN}^{-}$ratios in comparison to non-smokers ( $t$-test, $P<0.001$. [2-tailed]. Table 3).

\section{Prediction of thyroid volume through single parameters}

Moreover, we performed ANOVA to investigate which of the single parameters: age. smoking. gender. body weight. body height. pregnancy or nursing period. urinary $\mathrm{I}^{-}$excretion. urinary $\mathrm{SCN}^{-}$excretion and urinary $\mathrm{I}^{-} / \mathrm{SCN}^{-}$ratio. can predict the dependent variable thyroid volume. ANOVA reveals a prediction of thyroid volume through: age $(P<0.001)$. gender $(P<0.001)$. smoking $(P<0.05)$ and body weight $(P<0.05)$. Because the hypothesis is that smoking generates $\mathrm{SCN}^{-}$. that causes goiter we have to define $\mathrm{SCN}^{-}$as an intermediate variable that can therefore not be included in the same model as tobacco smoking without providing misleading results. We have to consider different effects: 1. The within-subjects mean effect: the influence of $\mathrm{SCN}^{-}$on thyroid volume, and 2 . The between-subjects interaction effect: does the influence of $\mathrm{SCN}^{-}$on thyroid volume depend on smoking? For those reasons we did not include $\mathrm{SCN}^{-}$in the same ANOVA model as tobacco smoking. ANOVA did not show a prediction of thyroid volume through $\mathrm{SCN}^{-}$. 


\section{Discussion}

Despite considerable improvements in the iodide supply in Saxony. 11\% of the probands in our study showed goiter (Table 1). In this context the urinary $\mathrm{I}^{-} / \mathrm{SCN}^{-}$ ratios were significantly lower in probands with goiter compared with probands without thyroid enlargement (Table 2). Previous investigations have suggested an increased risk for the development of goiter in probands with low urinary $\mathrm{I}^{-} / \mathrm{SCN}^{-}$ratios (1. 10). In these studies thyroid volumes were more often found to be in the upper normal limit. if probands had urinary $\mathrm{I}^{-} / \mathrm{SCN}^{-}$ratios below $4 \mu \mathrm{g} / \mathrm{mg}(1,10)$. In the beginning of the 90s. probands with goiter in the industrial area of Halle/Leipzig were found to have such a risk constellation with urinary $\mathrm{I}^{-} / \mathrm{SCN}^{-}$ratios of $3.5 \mu \mathrm{g} / \mathrm{mg}$ (10). Our present investigation in the same area demonstrated a marked increase in mean urinary $\mathrm{I}^{-} / \mathrm{SCN}^{-}$ratios $\left(41 \mu \mathrm{g} \mathrm{I}^{-} / \mathrm{mg} \mathrm{SCN}^{-}\right)$in probands with thyroid enlargement (Table 2). This finding is most likely due to the increased urinary $\mathrm{I}^{-}$excretion in Saxony (14) based on a rise in the ambient $\mathrm{I}^{-}$supply. Contrary to the results of a previous investigation in Italy, which stated that the prevalence of goiter is restricted to $\mathrm{I}^{-}$deficiency (based on urinary $\mathrm{I}^{-}$ excretion level), but is not correlated to $\mathrm{SCN}^{-}$(27). Our results demonstrate that $\mathrm{SCN}^{-}$is a cofactor or indicator for goiter in non-smokers $\left(\mathrm{SCN}^{-}\right.$is an independent determinant) as well as smokers. $\mathrm{SCN}^{-}$, a major component of tobacco smoke, inhibits $\mathrm{I}^{-}$uptake by the thyroid gland and $\mathrm{SCN}^{-}$correlates with the intensity of smoking $(10,28)$. Based on the WHO criteria for urinary $\mathrm{I}^{-}$excretion, only 15 of 79 probands with goiter showed moderate to severe $\mathrm{I}^{-}$deficiency $\left(<50 \mu \mathrm{g} \mathrm{I}^{-} / \mathrm{g}\right.$ creatinine $)(20,21)$. The remaining participants with goiter showed urinary $\mathrm{I}^{-}$excretion levels within the lower range of adequate $\mathrm{I}^{-}$intake (100 $\mathrm{\mu g}^{-} / \mathrm{g}$ creatinine) $(20,21)$. The $\mathrm{I}^{-}$status of probands, determined by urinary $\mathrm{I}^{-}$excretion measurements or by $\mathrm{I}^{-}$intake estimation using a questionnaire, may modulate the response to smoking (3, 28-30). Smoking has antithyroid properties, especially if the $\mathrm{I}^{-}$status is low $(28,30)$. Moreover, recommendations for the $\mathrm{I}^{-}$intake levels, have to consider different incidences of malignant and immunogenic thyroid disorders in different age groups $(30,31)$. Therefore, the $\mathrm{I}^{-}$intake level should be brought to the lowest levels (not the higher levels) to avoid $\mathrm{I}^{-}$ deficiency disorders. However, the optimal $\mathrm{I}^{-}$intake level remains to be determined (30). Mean $\mathrm{SCN}^{-}$ excretion levels (3.2 $\mathrm{mg} \mathrm{SCN}^{-} / \mathrm{g}$ creatinine) in our probands were lower than in a previous investigation (6.8 $\mathrm{mg} \mathrm{SCN}^{-} / \mathrm{g}$ creatinine) by Kramer et al. (10) conducted in the same area in 1990. This was expected and mostly based on the elimination of industrial waste products and a decreased $\mathrm{CN}^{-}$pollution (13). $\mathrm{CN}^{-}$, is detoxified to $\mathrm{SCN}^{-}$when inhaled (polluted air or smoking) or absorbed (polluted foods), especially in industrial areas $(1,10,12) . \mathrm{CN}^{-}$has goitrogenous properties and may be relevant in the aetiology of thyroid disorders, particularly in $\mathrm{I}^{-}$deficient regions $(1,10)$. Moreover, the serum half-lives for $\mathrm{SCN}^{-}$of approximately 6 days is important, as $\mathrm{SCN}^{-}$persists for more than 20 times longer in the human serum than other goitrogenes, i.e. perchlorate or nitrate (32). Therefore the $\mathrm{I}^{-}$uptake inhibition by $\mathrm{SCN}^{-}$at the sodiumiodide symporter is most likely relevant in the etiology of goiter (32). In this context Delange et al. (1) described an increased risk for developing goiter in patients with urinary $\mathrm{I}^{-} / \mathrm{SCN}^{-}$ratio $<4$. The authors investigated $\mathrm{SCN}^{-}$-sources and measured urinary $\mathrm{I}^{-} / \mathrm{SCN}^{-}$ratios in patients with goiter and excessive consumption of cabbage in an area of moderate to severe $\mathrm{I}^{-}$deficiency (Sicily, Italy) and compared them with healthy probands from Belgium. The environmental $\mathrm{SCN}^{-}$ exposure through food, industrial waste products and smoking was not investigated in this study, because there are considerable geographic differences between both regions. A bias due to $\mathrm{CN}^{-}$incorporation via air pollution or other foods than cabbage can not be excluded. The causes for the differences in urinary $\mathrm{SCN}^{-}$and $\mathrm{I}^{-}$excretion levels, between probands in Italy and Belgium and the role of $\mathrm{SCN}^{-}$in the etiology of goiter in both regions remain unclear. Moreover, the authors suggested, that the increased prevalence of goiter in Sicily is most likely based on severe $\mathrm{I}^{-}$ deficiency and secondarily associated with goitrogenous properties of $\mathrm{SCN}^{-}$(1) In contrast Costa et al. (27) did not find any correlation between urinary $\mathrm{SCN}^{-}$excretion and goiter prevalence in Italy.

Table 1 Characteristics of the overall study population.

\begin{tabular}{|c|c|c|c|}
\hline & Males & Females & Study population \\
\hline Probands* & $132(19 \%)$ & $576(81 \%)$ & $708(100 \%)$ \\
\hline Age $^{\star *}$ (years) & $31 \pm 12$ & $36 \pm 13$ & $35 \pm 13$ \\
\hline Goiter* & $9(7 \%)$ & $70(12 \%)$ & $79(11 \%)$ \\
\hline Thyroid nodules* & $26(20 \%)$ & $179(31 \%)$ & 205 (29\%) \\
\hline Nodular goiter* & $7(5 \%)$ & $49(9 \%)$ & $56(8 \%)$ \\
\hline Previous thyroidectomy* & $2(2 \%)$ & $14(2 \%)$ & $16(2 \%)$ \\
\hline
\end{tabular}

*Number of probands; **Mean \pm S.D. 
Table 2 Urinary $\mathrm{SCN}^{-}$and $\mathrm{I}^{-}$excretions and urinary $\mathrm{I}^{-} / \mathrm{SCN}^{-}$ratios of the overall study population.

\begin{tabular}{|c|c|c|c|c|}
\hline & $\begin{array}{l}\text { Urinary } \mathbf{S C N}^{-} \text {excretion } \\
\quad(\mathrm{mg} \mathrm{SCN} \\
\end{array}$ & $\begin{array}{l}\text { Urinary } \mathrm{I}^{-} \text {excretion }{ }^{\star \star} \\
\left(\mu \mathrm{g} \mathrm{I}^{-} / \mathrm{g} \text { creatinine }\right)\end{array}$ & $\begin{array}{l}\text { Urinary } \mathrm{I}^{-} / \mathrm{SCN}^{-} \text {ratio }^{* *} \\
\left(\mu \mathrm{I}^{-} / \mathrm{mg} \mathrm{SCN}^{-}\right) / \mathrm{I}\end{array}$ & $\begin{array}{l}\text { Thyroid volume } \\
\text { (ml) }\end{array}$ \\
\hline Study population $\left(n=708^{*}\right)$ & $3.2 \pm 3.3[\mathrm{f}]$ & $108 \pm 81$ & $58 \pm 68[f]$ & $13 \pm 7$ \\
\hline Normal thyroid volume $\left(n=629^{\star}\right)$ & $3.1 \pm 3.4[a, b]$ & $102 \pm 96$ & $61 \pm 71[\mathrm{c}]$ & $11 \pm 4$ \\
\hline (Nodular) goiter $\left(n=79^{*}\right)$ & $3.9 \pm 2.8[\mathrm{a}]$ & $96 \pm 74$ & $41 \pm 38[c]$ & $28 \pm 11$ \\
\hline Males with goiter $(n=9)$ & $4.0 \pm 3.0$ & $75 \pm 21$ & $26 \pm 13[e]$ & $45 \pm 18$ \\
\hline $\begin{array}{l}\text { Males with normal thyroid } \\
\text { volume }(n=123)\end{array}$ & $2.8 \pm 2.6$ & $76 \pm 45$ & $49 \pm 50[\mathrm{e}]$ & $13 \pm 5$ \\
\hline Females with goiter $(n=70)$ & $4.0 \pm 2.8[\mathrm{~b}]$ & $114 \pm 92$ & $43 \pm 40[d]$ & $26 \pm 8$ \\
\hline $\begin{array}{l}\text { Females with normal thyroid } \\
\text { volume }(n=506)\end{array}$ & $3.2 \pm 3.5$ & $117 \pm 86$ & $63 \pm 75[d]$ & $10 \pm 4$ \\
\hline Thyroid nodules $\left(n=205^{\star}\right)$ & $3.5 \pm 3.5$ & $108 \pm 115$ & $57 \pm 62$ & $16 \pm 10$ \\
\hline Males $\left(n=132^{*}\right)$ & $2.9 \pm 2.6$ & $79 \pm 44$ & $47 \pm 49$ & $15 \pm 10$ \\
\hline Females $\left(n=576^{*}\right)$ & $3.3 \pm 3.5$ & $120 \pm 127$ & $61 \pm 72$ & $12 \pm 7$ \\
\hline Pregnancy/lactation period $\left(n=23^{*}\right)$ & $4.1 \pm 3.7[f]$ & $145 \pm 272$ & $41 \pm 68$ [f] & $13 \pm 6$ \\
\hline
\end{tabular}

$\mathrm{SCN}^{-}$excretion and $\mathrm{I}^{-}$excretion were correlated with creatinine excretion in every spot urine sample to minimize bias through kidney function and variable 24-hour urinary volume. Alphabetic characters in brackets $[\mathrm{a}-\mathrm{f}]$ demonstrate the corresponding differences at the significant $P<0.05$ level.

*Number of probands; **Mean \pm S.D.

The authors found highly variable levels of $\mathrm{SCN}^{-}$ excretion, ranging from $1.24 \pm 0.57 \mathrm{mg} / \mathrm{l}$ to $8.08 \pm 5.5 \mathrm{mg} / \mathrm{l}$ in different regions, which may have compromised the statistical analysis. In this study the inverse correlation between urinary $\mathrm{I}^{-} / \mathrm{SCN}^{-}$excretion levels and goiter was exclusively based on lower $\mathrm{I}^{-}$ excretion in patients with increased thyroid volume (27). Up to now, a relationship between goiter and increased $\mathrm{SCN}^{-}$excretion (in patients with similar $\mathrm{I}^{-}$ status) could only be demonstrated in epidemiological surveys in Africa (33). In contrast to our study population, these African populations showed severe $\mathrm{I}^{-}$ deficiency (33). Based on the analyses of non-smokers, the $\mathrm{SCN}^{-}$excretion correlated $(P=0.068)$ with thyroid volume. However, a general causal thyrostatic effect of $\mathrm{SCN}^{-}$could not be identified. As expected the individual risk for developing goiter increases with tobacco smoking (3). Smoking increases the $\mathrm{CN}^{-}$ absorption of the human body $(4,10,11)$. In our study smokers had a tendency towards higher values for thyroid volume in comparison to non-smokers, without reaching statistical significance (Table 3). Because prevalence of goiter increases with age and decreases with increased $\mathrm{I}^{-}$intake $(3,29,34,35)$, the younger mean age of our population as well as the elimination of severe $\mathrm{I}^{-}$deficiency in Saxony (14) may obscure to the (insignificant) difference between smokers and non-smokers. We are aware that the $30 \%$ non-response regarding smoking behaviour could cause some selection bias. Previous investigators found an increased risk for developing a goiter due to elevated $\mathrm{SCN}^{-}$concentrations of $8-12 \mathrm{mg} / \mathrm{l}$ (normal $2-4 \mathrm{mg} / \mathrm{l})$ in the serum of smokers in comparison to nicotine abstinence $(11,36,37)$. Our results show an elevated risk for developing a goiter beginning with urinary $\mathrm{SCN}^{-}$concentrations $>3,5 \mathrm{mg} \quad \mathrm{SCN}^{-} / \mathrm{g}$ creatinine.

The population based Study of Health in Pomerania (35) in a formerly $\mathrm{I}^{-}$-deficient region showed, that thyroid enlargement is associated with advanced age and

Table 3 Urinary $\mathrm{SCN}^{-}$and $\mathrm{I}^{-}$excretions and urinary $\mathrm{I}^{-} / \mathrm{SCN}^{-}$ratios of 491 probands with known smoking behaviour.

\begin{tabular}{|c|c|c|c|c|}
\hline & $\begin{array}{l}\text { Urinary } \mathrm{SCN}^{-} \text {excretion } \\
\quad\left(\mathrm{mg} \mathrm{SCN}^{-} / \mathrm{g} \text { creatinine }\right)\end{array}$ & $\begin{array}{l}\text { Urinary } \mathrm{I}^{-} \text {excretion } \\
\left(\mu \mathrm{g} \mathrm{I}^{-} / \mathrm{g} \text { creatinine }\right)\end{array}$ & $\begin{array}{l}\text { Urinary } \mathrm{I}^{-} / \mathrm{SCN}^{-} \text {ratio**} \\
\qquad\left(\mu \mathrm{g} \mathrm{I}^{-} / \mathrm{mg} \mathrm{SCN}^{-}\right) / \mathrm{I}\end{array}$ & $\begin{array}{l}\text { Thyroid volume } \\
\text { (ml) }\end{array}$ \\
\hline Smoker $\left(n=124^{\star}\right)$ & $4.3 \pm 4.3[\mathrm{j}, \mathrm{l}]$ & $114 \pm 79[1]$ & $45 \pm 47[\mathrm{k}, \mathrm{l}]$ & $14 \pm 8$ \\
\hline $\begin{array}{l}\text { Smoker with normal } \\
\text { thyroid volume }\left(n=99^{\star}\right)\end{array}$ & $4.2 \pm 4.6$ & $124 \pm 83$ & $51 \pm 51$ & $11 \pm 6$ \\
\hline Smoker with goiter $\left(n=25^{\star}\right)$ & $4.8 \pm 3.1[1]$ & $79 \pm 44[1]$ & $21 \pm 13[1]$ & $26 \pm 7$ \\
\hline Smoker with thyroid nodules $\left(n=37^{\star}\right)$ & $4.0 \pm 3.3$ & $101 \pm 63$ & $42 \pm 43$ & $18 \pm 8$ \\
\hline Nonsmoker $\left(n=367^{*}\right)$ & $2.4 \pm 2.1[j]$ & $113 \pm 88$ & $60 \pm 61[k]$ & $13 \pm 8$ \\
\hline $\begin{array}{l}\text { Nonsmoker with normal } \\
\text { thyroid volume }\left(n=324^{\star}\right)\end{array}$ & $3.1 \pm 3.4$ & $113 \pm 87$ & $61 \pm 63$ & $11 \pm 4$ \\
\hline Nonsmoker with goiter $\left(n=43^{*}\right)$ & $3.0 \pm 1.9$ & $114 \pm 94$ & $51 \pm 48$ & $28 \pm 12$ \\
\hline $\begin{array}{l}\text { Nonsmoker with thyroid nodules } \\
\left(n=116^{*}\right)\end{array}$ & $3.2 \pm 3.9$ & $133 \pm 113$ & $67 \pm 71$ & $15 \pm 10$ \\
\hline
\end{tabular}

$\mathrm{SCN}^{-}$excretion and $\mathrm{I}^{-}$excretion were correlated with creatinine excretion in every spot urine sample to minimize bias through kidney function and variable 24-hour urinary volume. Alphabetical characters in brackets [j-I] demonstrate the corresponding differences at the significant $P<0.05$ level.

*Number of probands; **Means \pm S.D. 
current smoking. Völzke et al. found higher urinary $\mathrm{SCN}^{-}$excretion in males with goiter in comparison to men without, but no correlation of renal $\mathrm{SCN}^{--}$ excretion with goiter of the overall study population $(n=3.915)$. The authors (35) suggested a role of environmental $\mathrm{SCN}^{-}$smoking) in the development of thyroid enlargement, but could not exclude a misclassification of smokers due to information bias. Our investigation conducted in an area with borderline $\mathrm{I}^{-}$ deficiency indicates a significant correlation of urinary $\mathrm{SCN}^{-}$excretion of the overall study population with the thyroid volume and probands with goiter had higher urinary $\mathrm{SCN}^{-}$excretions than probands without. Moreover, the $\mathrm{SCN}^{-}$effects on the thyroid volume depend on $\mathrm{SCN}^{-}$concentrations, urinary $\mathrm{I}^{-}$and urinary $\mathrm{I}^{-} / \mathrm{SCN}^{-}$ ratios $(10,11,35,38)$ as well as environmental and individual risk factors, especially the intensity of smoking $(10,11,35,37)$. Surprisingly, in contrast to $\mathrm{SCN}^{-}$ excretion, the urinary $\mathrm{I}^{-}$excretion of our probands did not correlate with thyroid volume, because the prevalence of goiter increases with age $(3,29,34)$. The small mean thyroid volume in our probands, especially in young male probands with moderate to severe $\mathrm{I}^{-}$ deficiency, most likely prevented an inverse correlation between urinary $\mathrm{I}^{-}$and thyroid volume.

In summary, our investigation shows that age, gender, body weight and smoking (increased $\mathrm{SCN}^{-}$levels by $\mathrm{CN}^{-}$ inhalation) were predicting factors for thyroid volume. The urinary $\mathrm{I}^{-} / \mathrm{SCN}^{-}$ratio was able to detect probands with an increased risk for goiter, in contrast to urinary $\mathrm{I}^{-}$ excretion levels alone. However, the etiology of goiter is an interplay between environmental, individual and genetic factors. Further research is needed to understand how factors such as smoking and $\mathrm{SCN}^{-}$influence the genetic susceptibility to develop goiter.

\section{References}

1 Delange F, Vigneri R, Trimarchi F, Filetti S, Pezzino V, Squatrito S, Bourdoux P \& Ermans AM. Etiological factors of endemic goiter in north-eastern Sicily. Journal of Endocrinological Investigations 1978 1 137-142.

2 Heinisch M, Kumnig G, Asbock D, Mikosch P, Gallowitsch HJ, Kresnik E, Gomez I, Unterweger O \& Lind P. Goiter prevalence and urinary iodide excretion in a formerly iodine- deficient region after introduction of statutory lodization of common salt. Thyroid $200212809-814$.

3 Knudsen N, Laurberg P, Perrild H, Bulow I, Ovesen L \& Jorgensen T. Risk factors for goiter and thyroid nodules. Thyroid $200212879-888$.

4 Krohn K, Führer D, Bayer Y, Eszlinger M, Brauer V, Neumann S \& Paschke R. Etiology of euthyroid and toxic multinodular goiter. Endocrine Reviews 200526 504-524.

5 Willett WC. Balancing life-style and genomics research for disease prevention. Science 2002296 695-698.

6 Kahaly GJ \& Dietlein M. Cost estimation of thyroid disorders in Germany. Thyroid 200212 909-914.

7 Weuffen W, Kramer A, Below H, Bohland H, Julich WD, Thurkow B \& Burth U. The thiocyanate ion as a physiologically significant active substance in living nature. Pharmazie 1990 $4516-29$.
8 Virion A, Deme D, Pommier J \& Nunez J. Opposite effects of thiocyanate an tyrosine iodination and hormone synthesis. European Journal of Biochemistry 1980112 1-7.

9 Laurberg P, Andersen S, Knudsen N, Ovesen L, Nohr SB \& Bulow Pedersen I. Thiocyanate in food and iodine in milk: from domestic animal feeding to improved understanding of cretinism. Thyroid 200212 897-902.

10 Kramer A, Meng W, Reinwein D, Weuffen W, Below H, Ermisch U, Julich WD, Koch S, Kellner R \& Meng S. Experimental and epidemiological studies on the interrelationship of thiocyanate and thyroid function. Zeitschrift Gesamte Hygiene 199036 383-387.

11 Kramer A, Pitten FA \& Zöllner H. Einfluss von Thiocyanat auf die Schilddrüse in Hinblick auf Empfehlungen für eine thiocyanatreiche Ernährung. Deutsche Lebensmittel Rundschau 19981 83-88.

12 Seifert B, Becker K, Helm D, Krause C, Schulz Cn \& Seiwert M. The German Environmental Survey 1990/1992 (GerES II): Reference Concentrations of Selected Environmental Pollutants in Blood, Urine, Hair, House Dust, Drinking Water and Indoor Air. Journal of Exposure Analysis Environmental Epidemiology 200010 $552-565$.

13 WHO. Collaborating Centre for Air Quality Management and Air Pollution Control. Newsletter 200127 1-28.

14 Gruning T, Zophel K, Wunderlich G \& Franke WG. Prevalence of goiter and iodine deficiency in Saxony is less than previously assumed. A study 6 years after discontinuation of general iodization of table salt. Medizinische Klinik 200196 1-8.

15 Lorenz-Wawschinek O, Tiran B, Eber O \& Langsteger W. Photometric Determination of Iodine in Urine. Experimental and Clinical Endocrinology 1994102 57-58.

16 Sandell EB. Micro determination of iodine by a catalytic method. Mikrochem Acta 19371 9-25.

17 Jaffe M. Überden niederschlag, welchen pikrinsäure in normalem Harn erzeugt und Über eine neae reaction des kreatins. Zeitschrift Physiologische Chemie 188610 391-400.

18 Below H \& Weuffen W. Zur Anwendbarkeit der Chlorcyan-PyridinBarbitursäure-Methode für die Thiocyanatbestimmung in Serum und Urin. Wissenschoftliche Zeitschrift Universität Greifswald 1987 $36120-124$.

19 Zöllner H, Als C, Gerber H, Hampel R, Kirsch G \& Kramer A. Screening for iodine deficiency iodide concentration or creatinine quotient in random urine. G.I.T. Laboratory Journal 20013 $138-139$.

20 Delange F, de Benoist B \& Burgi H. Determining median urinary iodine concentration that indicates adequate iodine intake at population level. Bulletin of the World Health Organisation 2002 80 633-636.

21 WHO, ICCIDD. Assessment of the iodine deficiency disorders and monitoring their elimination. Geneva, 2001.

22 Hegedus L, Perrild H, Poulsen LR, Andersen JR, Holm B, Schnohr P, Jensen G \& Hansen JM. The determination of thyroid volume by ultrasound and its relationship to body weight, age, and sex in normal subjects. Journal of Clinical Endocrinology \& Metabolism 198356 260-26.

23 Knudsen N, Bols B, Bulow I, Jorgensen T, Perrild H, Ovesen L \& Laurberg P. Validation of ultrasonography of the thyroid gland for epidemiological purposes. Thyroid 19999 1069-1074.

24 Gutekunst R, Becker W, Hehrmann R, Olbricht T \& Pfannenstiel P. Ultrasonic diagnosis of the thyroid gland. Deutsche Medizinische Wochenschrift 1988113 1109-1112.

25 Manz F, Bohmer T, Gartner R, Grossklaus R, Klett M \& Schneider R. Quantification of iodine supply: representative data on intake and urinary excretion of iodine from the German population in 1996. Annals of Nutrition and Metabolism 200246 128-138.

26 Gunton JE, Hams G, Fiegert M \& McElduff A. Iodine deficiency in ambulatory participants at a Sydney teaching hospital: is Australia truly iodine replete? Medical Journal of Australia 1999 $171467-470$.

27 Costa A, De Filippis V, Barbeni M, Bestagno M, Giraudi G \& Grillo C. Thiocyanates and iodine in endemic goiter in Italy. Journal of Endocrinological Investigations 19847 103-110. 
28 Tzlomalos K \& Charsoulis F. Endocrine effects of tobacco smoking. Clinical Endocrinology $200461664-674$.

29 Knudsen N, Perrild H, Christiansen E, Rasmussen S, DigePetersen $\mathrm{H}$ \& Jorgensen T. Thyroid structure and size and twoyear follow-up of solitary cold thyroid nodules in an unselected population with borderline iodine deficiency. European Journal of Endocrinology $2000142224-230$.

30 Laurberg P, Nohr SB, Pedersen KM, Hreidarsson AB, Andersen S, Bulow Pedersen I, Knudsen N, Perrild H, Jorgensen T \& Ovesen L. Thyroid disorders in mild iodine deficiency. Thyroid $2000 \mathbf{1 0}$ 951-963.

31 Laurberg P, Bulow Pedersen I, Knudsen N, Ovesen L \& Andersen S. Environmental iodine intake affects the type of nonmalignant thyroid disease. Thyroid 200111 457-469.

32 Tonacchera M, Pinchera A, Dimida A, Ferrarini E, Agretti P, Vitti P, Santini F, Crump K \& Gibbs J. Relative potencies and additivity of perchlorate, thiocyanate, nitrate and iodide on the inhibition of radioactive iodide uptake by the human sodium iodide symporter. Thyroid $2004141012-1019$.

33 Courtois P, Bourdoux P \& Lagasse R. Role of the balance between the dietary supplies of iodine and thiocyanate in the etiology of endemic goitre in the Ubangi area. In Nutritional Factors Involved in the Goitrogenic Action of Cassava, Ottawa, pp 65-69. Eds
F Delange, FB Iteke \& AM Ermans. 1982: International Development Research Centre.

34 Aghini-Lombardi F, Antonangeli L, Martino E, Vitti P, Maccherini D, Leoli F, Rago T, Grasso L, Valeriano R, Balestrieri A \& Pinchera A. The spectrum of thyroid disorders in an iodine-deficient community: the Pescopagano survey. Journal of Clinical Endocrinology and Metabolism $1999 \mathbf{8 4} 561-566$.

35 Völzke H, Lüdermann J, Robinson DH, Spieker KW, Schwahn C, Kramer A, John U \& Meng W. The prevalence of undiagnosed thyroid disorders in a previously iodine-deficient area. Thyroid, $200313803-810$.

36 Abou-Seif M. Blood antioxidant status and urine sulfate and thiocyanate levels in smokers. Journal of Biochemical Toxicology 1996 11 133-138.

37 Erdogan M. Thiocyanate overload and thyroid disease. Biofactors $200319107-111$.

38 Delange F \& Ermans A. Endemic goiter and cretinism. Naturally occurring goitrogens. Pharmacological Therapy 19761 57-93.

Received 19 April 2005

Accepted 19 October 2005 